The African Academic

\section{Diaspora and African Higher Education}

\section{Kim Foulds and Paul Tiyambe Zeleza}

Kim Foulds is program coordinator, Carnegie African Diaspora Fellowship Program. E-mail: kimberly.foulds@quinnipiac.edu.Paul Tiyambe Zeleza is vice president for academic affairs, both at Quinnipiac University, Hamden, CT. E-mail: paul.zeleza@quinnipiac.edu.

$\mathrm{T}$ he dominant discourse around the African academic diaspora follows a distinct pattern of deficit: the wideranging costs of losing some of the continent's best and brightest intellectuals. The focus on this deficit, however, clouds the expansive and often innovative relationships that African academic diasporans have forged with scholars and institutions across the continent-relationships that build and reinforce both scholarly and personal engagements. These relationships-primarily informal though many formal individual and institutional engagements do exist-are often neglected in discussions of internationalization because African universities have not been seen as legitimate partners for institutional engagement with North American and European universities. In terms of valuing academic enterprise and commitment to producing innovative and dynamic scholarship, universities have overlooked African institutions, renewing and reinforcing existing gaps in knowledge production.

\section{The African Academic Diaspora}

A recent study by Paul Tiyambe Zeleza-Engagements between African Diaspora Academics in the U.S. and Canada and African Institutions of Higher Education: Perspectives from North American and Africa (Carnegie Corporation of New York, February 2013) - sheds much needed light on which African academic diasporans are in the United States and Canada, as well as the existence of engagements between the diaspora and African higher education. According to the study, the African-born academic diaspora in North America has grown rapidly over the last three decades, in part due to the severe economic challenges and political repression that faced African countries and universities in the I980s and I990s. Many African diaspora academics have established vibrant, albeit largely informal, engagements with individuals and/or institutions across Africa. Ranging from research collaborations to curriculum development and graduate student supervision, these engagements are often frustrated by institutional and attitudinal barriers, on both sides of the Atlantic. Some of the major obstacles in- clude differences in resources and facilities, expectations, academic status, teaching loads, institutional priorities, and scheduling around incompatible academic terms between the sending and receiving institutions. The study reveals traditional structures, and systems of faculty exchange are inadequate to alleviate these barriers.

\section{Recent Developments}

Recently, there have been significant efforts made to address these gaps and to support African universities for purposes of international engagement. Many of these efforts have been spearheaded or supported by philanthropic foundations. The most well known example is the Partnership for Higher Education in Africa that brought together seven foundations (Carnegie Corporation of New York, Ford, Rockefeller, MacArthur, Hewlett, Mellon, and Kresge) and invested US\$440 million in the revitalization of African universities between 2000-20I0. Often missing in these efforts and in the internationalization of American higher education, the critical and transformative role the academic diasporas can already play. Compared to the voluminous literature on the role of diasporas in the economic development of their homelands, through remittances and investment, not much is known about their role in the development of systems of knowledge production including universities. The academic diaspora is a rich source of intellectual remittances."

\section{Many African diaspora academics have established vibrant, albeit largely in- formal, engagements with individuals and/or institutions across Africa.}

\section{Carnegie African Diaspora Fellowship Program}

Current models of faculty exchange remain relatively static, operating within a two- or three-tiered system: funding organization, sending institution(s), and receiving institution(s). Out of Zeleza's study, a new model has been established through the Carnegie African Diaspora Fellowship Program. The program establishes a novel partnership between four parties: Carnegie Corporation of New York with funding, the International Institute for Education with logistical support, Quinnipiac University with administrative support, and an Advisory Council comprised of leading African academics and university administrators in North America and Africa with strategic direction. The program will serve as the springboard for increased institutional af- 
filiations between American and Canadian universities and institutions across Africa by demonstrating that, though Africa has long been neglected as a site of ground-breaking research; and knowledge production across the disciplines, the continent-its institutions, scholars, and students-can no longer be ignored if American and Canadian universities are in fact committed to producing globally rigorous scholarship and world-class students.

The program will focus on three-key areas: increased research collaboration; curriculum codevelopment between diaspora academics, their home institutions, and African institutions and faculty; and graduate student teaching and mentoring. Unlike existing exchange programs, in this program African institutions will drive the structure of exchanges and engage the desire of diaspora academics to contribute to higher education across Africa. Through the program, African institutions in Ghana, Kenya, Nigeria, South Africa, Tanzania, and Uganda submit a proposalrequesting the expertise of a diaspora scholar in the three areas or to be matched with an interested diaspora scholar for the appropriate disciplinary expertise.

The goal of this program and model to ensure that African institutions are the driving forces in identifying needs and opportunities for engagement, as well as providing to diaspora scholars and African institutions the space to build and expand their scholarly alliances. While the brain drain is a very real phenomenon, engaging the African academic diaspora and establishing programs to promote academic exchanges and collaborations holds potential for internationalizing and strengthening the capacities of African universities.

\section{China: Reforming the Gaokao}

\section{Gerard A. Postiglione}

Gerard A. Postiglione is Chair in Sociology and Education Policy, associate dean for research, and director of the Centre of Research on Education in China, Faculty of Education, University of Hong Kong, China.E-mail: postiglione@hku.hk.

nother reform is soon to be under way for China's Agaokao - the national college and university entrance exam that remains the greatest determinant of a Chinese student's life chances. Beside the reform of the English component (see Yang Rui in IHE No. 75: 12-13), there is a new move to align the test with China's moderating economic growth. In this sense, the gaokao is also a barom- eter of the challenges facing China's economic rise and its breakneck expansion of higher education.

\section{China's Dictum: Seek Truth From Facts}

Fact one: Before graduation last May 20I3, only about half of the nearly 7 million graduates had signed job contracts. Many university graduates would come to find themselves underemployed and facing a skills-mismatch problem. In a nation that is still more rural than urban and that families must make great sacrifices to pay for their children's higher education, it is disconcerting to the average parent when a student who passes the grueling national examination and attends university cannot find a good job.

Fact two: I7 million high school and college graduates enter the labor market every year, but state planners are concerned that the nation suffers from a shortage of talent, particularly in technical fields. Although China will have almost 200 million college graduates by 2020 , it will require far more expertise to elevate the value chain for equipment manufacturing, information technology, biotechnology, new materials, aeronautics and astronautics, oceanography, finance and accounting, international business, environmental protection, energy resources, agricultural technology, and modern traffic and transportation. To sustain its economic rise, the nation has to wean itself off of low-wage assembly export manufacturing. While it has top-notch scientists, it cannot upgrade its manufacturing sector without a greater number of well-trained technicians. While there is still concern that the education system does not encourage innovation and creativity, there is also a demand for technicians with a higher education that can support the ratcheting up of production.

Fact three: Students and their families still view technical-professional education as second class. The viewpoint dies hard, since academic higher education traditionally has equaled a stable job with government agency.

\section{Pending Reforms}

Thus, China will soon unveil a reform plan for the gaokao, which will divide it into two separate test modes, one for technically inclined students and the other for the more traditionally academically oriented students. The technical gaokao leads to higher technical and professional education-specifically toward admission to 600 technical and professional colleges and universities.

The first mode, targeting technically inclined students, is meant to appeal to those who want to become engineers, senior mechanics, and so-called high-quality laborers. It will assess students' technical skills, as well as textbook knowledge. The second mode still targets the standard academic student and examines characteristically academic knowledge. 